\title{
Private Developers' Perceived Challenges Regarding Private Estate Housing Production in Greater Port Harcourt: Nigeria
}

\author{
Dr (Mrs). Augusta Ayotamuno ${ }^{1}$, Dr Victor .Obinna ${ }^{2}$ \\ ${ }^{I}$ Institute of Geosciences and Space Technology, Rivers State University of Science and Technology, Port \\ Harcourt \\ ${ }^{2}$ Department of Urban and Regional Planning, Rivers State University of Science and Technology, Port \\ Harcourt
}

\begin{abstract}
The private sector remains the major supplier of housing in Nigeria as with some other developing countries. However, productivity in Nigeria is hampered by many factors, including high cost of building materials, difficulty in obtaining title to land, a weak mortgage financing sector, and delay in obtaining building permit. Therefore, the objectives of the research were to (1) Ascertain Private Developers' Perceived Challenges Regarding Private Housing Production (2) Ascertain Bottlenecks to Private Residential Estate Housing Delivery. This study was undertaken as a cross-sectional survey of all individuals or corporate firms who have supplied at least 4 building units and more constructed between 1978 and 2014 in Greater Port Harcourt City (GPHC). The research design used was the "passive-observational" method. The number of questionnaires administered to estate developers was 76. The study relied on two sources of information primary and secondary. Primary sources comprised (a) a largely pre-coded questionnaire, administered faceto-face by trained interviewers, (b) Individual Depth Interviews (IDIs) of key informants, (c) direct observation, (c) measurement, and (d) photography. Secondary sources included: (a) unpublished and published material in past theses, books, journals, maps, etc; and (b) the Internet. Data analysis utilised mainly univariate and multivariate statistical analytical techniques. Analysis was carried out with the aid of the microcomputeradapted Statistical Package for the Social Sciences (SPSS), version 16. The results showed that 1,761 housing units were built by the private sector and this was mostly in Obio/Akpor LGA (80\%). Housing types were single-family bungalow (28.3\%), multi-family block of flats (26.8\%), single-family storey building (18.8\%), "wagon" rooming house (4.3\%) and "courtyard" rooming house (1.8\%). Four predictor variables -- Access to Land, Mortgage Financing, Building Permit, and Title to Land could explain 85\% of the variation in the dependent variable, Private Housing Productivity, with Title to Land being the most important. The study concluded, among others, that (a) the pace of private sector housing development in Greater Port Harcourt City was far short of what is needed to satisfy demand, given a population of the order of 2,000,000 growing at 5.8\% per annum. Recommendations of the study include (a) that the Land Use Act of 1978 should be abrogated.
\end{abstract}

Keywords: Private Estate, Private Developers, Perceived Challenges, Housing Production

\section{Introduction}

The private sector remains the major supplier of housing in Nigeria as with in some other developing countries. However, productivity in Nigeria is hampered by many factors, including high cost of building materials, difficulty in obtaining title to land, a weak mortgage financing sector, and delay in obtaining building permit. About $90 \%$ of total housing provision has traditionally been attributed to the private sector (Ajanlekoko 2001). However, Ogu (1999) noted that $54 \%$ of residential accommodation is being provided by individual private property developers; 22.7 percent by corporate developers; and 22.3 percent by government. Considering their poor economic circumstances, the low income group, which comprises the vast majority of Nigerians, has to rely also on cooperative housing to meet their needs. Unfortunately, the private sector is saddled with numerous problems, which cause supply to always fall far short of demand and lead to lower production quality (Nubi, 2008). Constraints to private housing production include funds shortage/ high cost of funds, high cost of construction, delay in obtaining Certificate of Occupancy ( $\mathrm{C}$ of $\mathrm{O}$ ) and building plan approval, land acquisition, high cost of building materials, and general government policy. In Greater Port Harcourt City, private developers are the key providers of housing as in other cities in Nigeria but the quantity and quality needs to be known. Most of the housing provided by individual developers are not necessarily in the form of housing estates but as disparate individual units, hence such developers are sometimes referred to "accidental landlords". Mass housing delivery in the form of estates is one major way of solving housing shortage globally and locally. This strategy is aimed at promoting accessibility to home ownership, reducing the affordability gap in home finance, and ensuring sustainable urbanization for the benefit of the citizens. 
This research will try to find out the level of private sector housing supply in estates during the period 1978 to 2014 in the study area and ascertain, among others, the peculiar challenges faced by private estate developers.

1.2 Aim

The aim of the study is to scientifically ascertain what private developers' perceive as challenges regarding private estate housing production in Greater Port Harcourt and proffer solutions to them.

\subsection{Objectives of the research were to;}

(1) Ascertain Private Developers' Perceived Challenges Regarding Private Housing Production in Greater Port Harcourt

(2) Ascertain Bottlenecks to Private Residential Estate Housing Delivery.

\section{Study Area}

Port Harcourt was founded in 1912 and it is the capital of Rivers State in southern Nigeria. It lies along the Bonny River (and eastern tributary of the Niger, 41 miles $(66 \mathrm{~km})$ upstream of the Gulf of Guinea. Its geographical coordinates are Longitude $07^{0} 01^{1} \mathrm{E}$ and Latitude $45^{0} 1^{1} \mathrm{~N}$ (Gobo, et al, 2014). The urban nature of Port Harcourt metropolis has undergone dramatic changes during the last decades. From a colonial city clearly delineated in its historic boundaries, Port Harcourt has grown and continues to grow into the surrounding landscape, swallowing even more villages, coastlines, and previously reserved landscape, transforming into an ever increasing urban conglomerate. After 1980s the city started experiencing rapid growth due to the increase in multi - national companies locating their headquarters in Port Harcourt. Port Harcourt experienced tremendous structural transformation due to the population and economic growth and development of its transportation and communication systems and the impact of globalization. There was an existing master plan of 1975 which was not fully implemented and was overdue for review.

In 2009 the Rivers State Government initiated the Greater Port Harcourt City Master Plan which is a holistic plan for the development of the Greater Port Harcourt City which spans eight (8) Local Government Areas namely; the whole of Port Harcourt Local Government Area (LGA) and parts of Oyigbo, Okrika, Ogu/Bolo, Obio/Akpor, Ikwerre, Etche ,Eleme LGAs with a population of approximately 2 million people. The Master Plan is for a period of 50 years, it will be reviewed periodically to ensure that it continues to meet with changing realities of an emerging city. The key anchors of the New City are the Port Harcourt International Airport, the Old City and Onne seaport. The Greater Port Harcourt City spans a total landmass of $19,000 \mathrm{~km}^{2}$ (Ede, Owei and Akarolo, 2008). Figure 1 shows the study area.

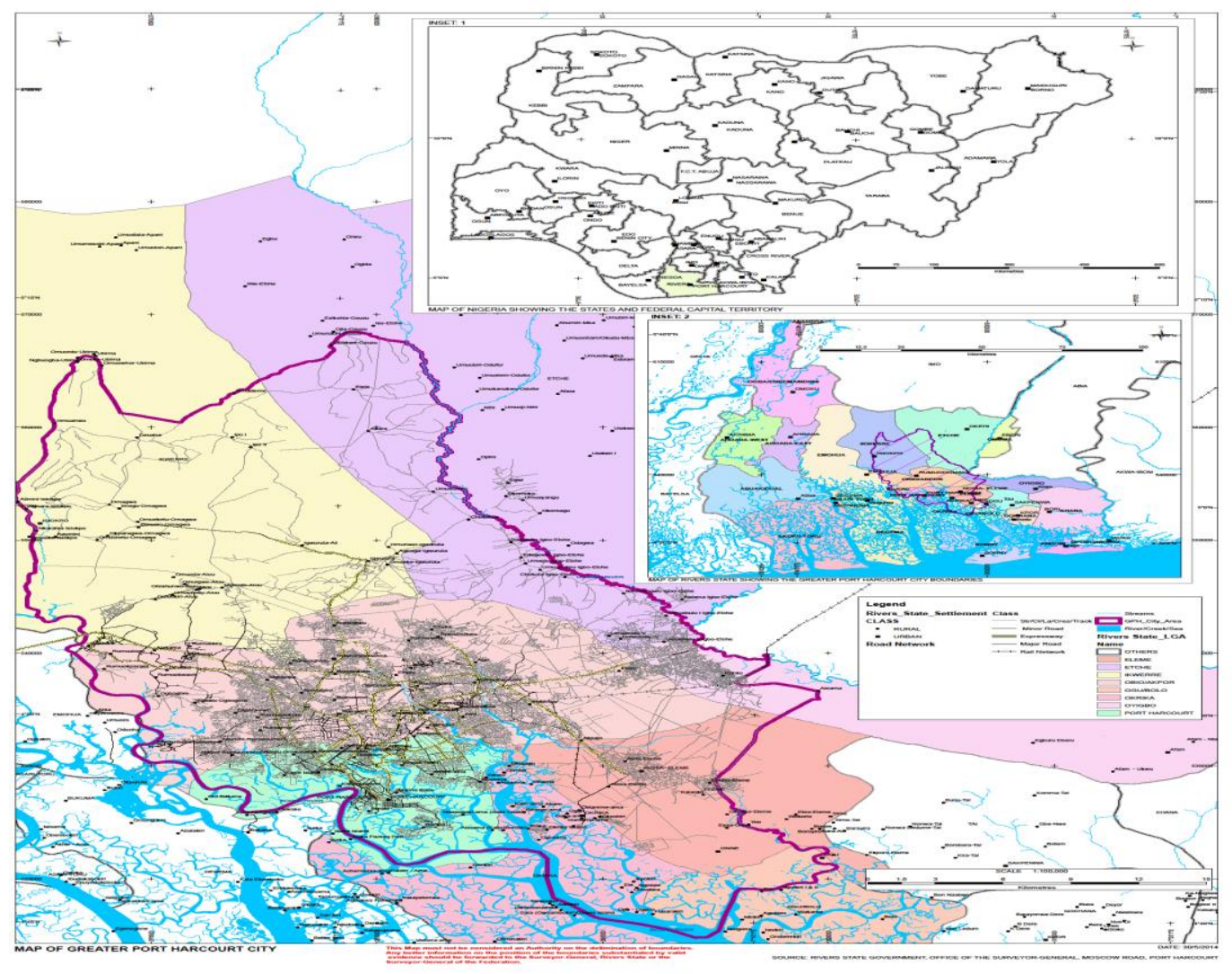

Fig1. Map of Greater Port Harcourt Area. Nigeria and Rivers State inset (1 \& 2) 


\section{Methodology}

This study was undertaken as a cross-sectional survey of all individuals or corporate firms who have supplied at least 4 building units and more constructed between 1978 and 2014 in Greater Port Harcourt City (GPHC) The research design used was the "passive-observational" method. The total number of relevant private developers was 100 (ascertained from field research). Since this number was relatively small, no sampling took place. Rather the research adopted a census of these developers. Of the 100 developers, 76 (seventy-six) responded. Therefore the analysis of responses was based on this number. The number of questionnaires administered to estate developers was 76. The study relied on two sources of information primary and secondary. Primary sources comprised (a) a largely pre-coded questionnaire, administered face-toface by trained interviewers, (b) Individual Depth Interviews (IDIs) of key informants, (c) direct observation, (d) measurement, and (e) photography. Secondary sources included: (a) unpublished and published material in past theses, books, journals, maps, etc; and (b) the Internet. Data analysis utilised mainly univariate and multivariate statistical analytical techniques. Analysis was carried out with the aid of the microcomputer - adapted Statistical Package for the Social Sciences (SPSS), version 16.

\section{Findings And Discussion}

Table 1: Privately Built Estates and the Total Number of Housing Units

\begin{tabular}{|l|l|l|l|}
\hline \multirow{2}{*}{ Year } & No of Estate & Housing Units & \\
\cline { 3 - 4 } & & No & \% \\
\hline 1978 & 5 & 192 & 8.8 \\
\hline 1981 & 2 & 36 & 2.4 \\
\hline 1983 & 8 & 94 & 6.3 \\
\hline 1984 & 10 & 120 & 8 \\
\hline 1985 & 4 & 40 & 2.7 \\
\hline 1986 & 8 & 251 & 14 \\
\hline 1997 & 1 & 10 & 0.66 \\
\hline 1998 & 1 & 36 & 2.4 \\
\hline 1999 & 2 & 20 & 1.33 \\
\hline 2000 & 3 & 64 & 4.26 \\
\hline 2001 & 15 & 366 & 17.7 \\
\hline 2003 & 1 & 14 & 0.93 \\
\hline 2005 & 6 & 86 & 5.73 \\
\hline 2006 & 10 & 180 & 8 \\
\hline 2007 & 1 & 10 & 0.66 \\
\hline 2008 & 9 & 106 & 7.06 \\
\hline 2010 & 2 & 50 & 3.33 \\
\hline 2012 & 12 & 86 & 5.73 \\
\hline Total & $\mathbf{1 0 0}$ & $\mathbf{1 7 6 1}$ & $\mathbf{1 0 0}$ \\
\hline
\end{tabular}

(Source: Author's Field Survey, November 2014)

The results showed that 1,761 housing units were built by the private sector and this was mostly in Obio/Akpor LGA (80\%). Housing types were single-family bungalow (28.3\%), multi-family block of flats (26.8\%), single-family storey building (18.8\%), "wagon" rooming house (4.3\%) and "courtyard" rooming house $(1.8 \%)$. Four predictor variables -- Access to Land, Mortgage Financing, Building Permit, and Title to Land could explain $85 \%$ of the variation in the dependent variable, Private Housing Productivity, with Title to Land being the most important.

Private housing developers were asked to state what they considered the most serious challenges to housing production. Results are shown in Table 2. The modal reported challenge was "scarcity of land for development" (26.8\%).

Table 2:.Perceived Challenges of Private Sector Housing Development

\begin{tabular}{|l|l|l|}
\hline Challenges & $\mathbf{N}$ & $\mathbf{\%}$ \\
\hline Scarcity of land & 20 & 26.8 \\
\hline High cost of land & 12 & 15.5 \\
\hline Challenges from LGA Agents & 5 & 6.6 \\
\hline Difficulty in obtaining building permit & 8 & 10.5 \\
\hline Low income flow & 19 & 26.3 \\
\hline High cost of transporting building materials & 7 & 9.2 \\
\hline Poor roads & 0 & 0 \\
\hline Non Response & 5 & 6.6 \\
\hline Total & $\mathbf{7 6}$ & $\mathbf{1 0 0}$ \\
\hline
\end{tabular}

(Source: Author's Field Survey, November 2014) 
Private Developers' Perceived Challenges Regarding Private Estate Housing Production in..

Income Level of Private Developers

Figure 2: shows the income level of private developers. The modal income bracket was "Less than N10 million"

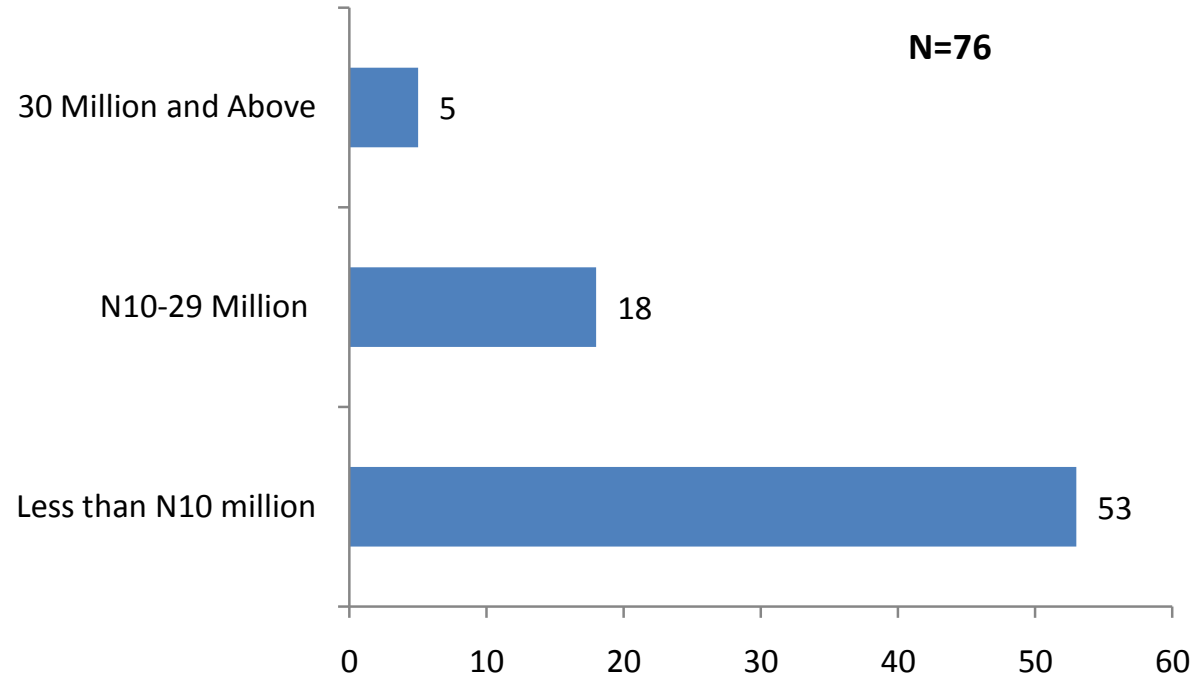

Figure 2:Income level of Developers

(Source: Author's Field Survey, November 2014)

\section{Mode of Acquisition of Building Land}

Figure 3 shows mode of acquisition of building land. The mode was by purchase (70\%).

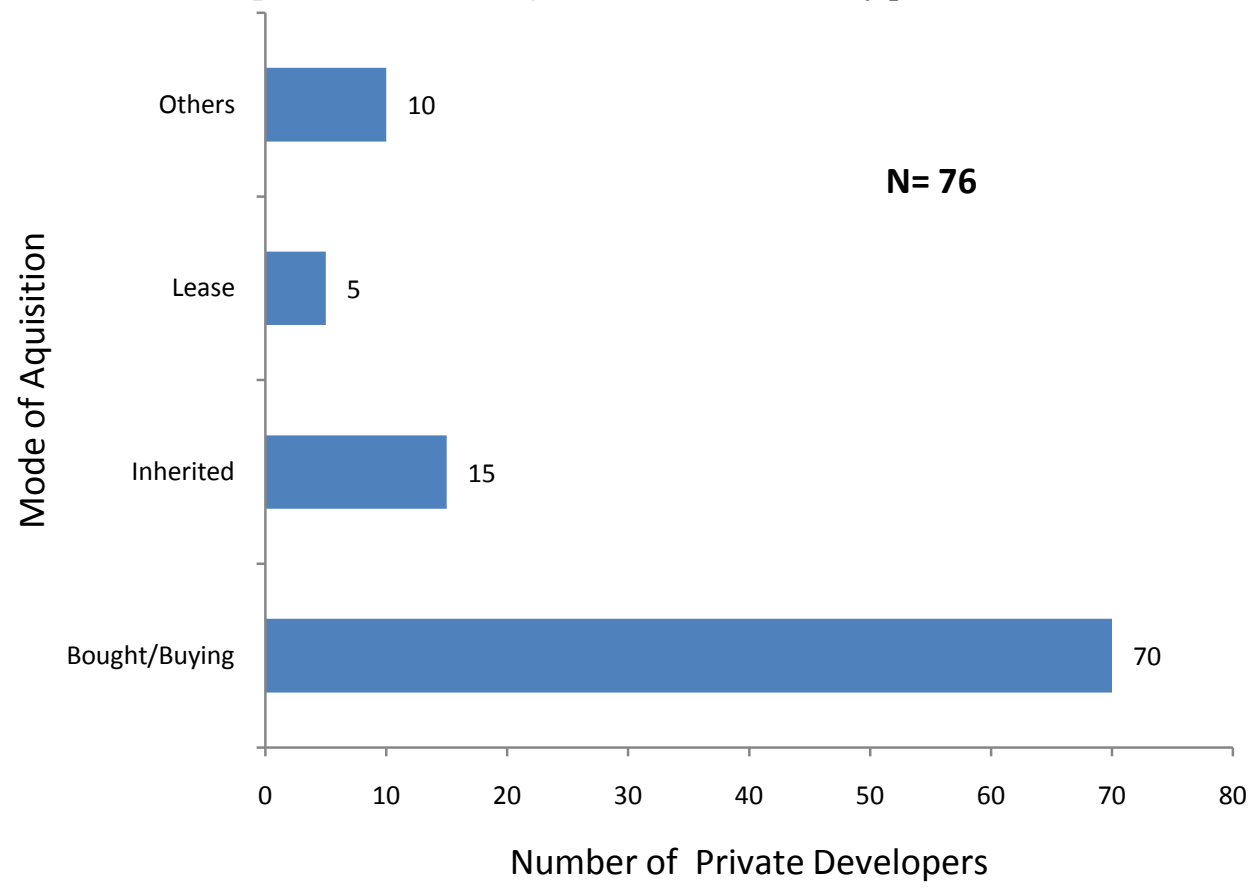

Figure 3:Acquisition of Land

(Source: Author's Field Survey, November 2014)

Private developers reported that the greatest challenge they experienced was scarcity of land. This can be explained with reference to the land stock situation in the built - up area of GPHC. Land is finite and there is diminishing land stock, while demand far outstrips the supply. Scarcity of land has driven up prices. For instance, in a recent unpublished survey a plot of land in Rumuwoji sold for $\mathrm{N} 30$ million. Low income flow was another challenge faced by private developers. Income flow deals with both availability and accessibility of funds. In other words, private developers were saying that they lacked adequate funds to execute housing projects. 


\section{Conclusions}

At the end of the research the following conclusions were made about private housing development in Greater Port Harcourt City (GPHC). First, the pace of private sector housing development was found to be far short of what is needed to satisfy the demand, given a population of the order of 2,000,000 supposed to be growing at 5.8\% per annum (the average urban annual growth rate as determined by the National Population Commission). Private developers surveyed were apparently not concerned with providing housing to meet the needs of all strata in the society, but have hitherto concentrated on the medium and high income groups.

Second, access to land is contributing negatively to housing productivity in GPHC. Private developers stated that there was limited land available and its cost was prohibitive. This has a multiplier effect since difficulty of access limits the number of plots that can be purchased, then types of houses to be built and eventually the quantity.

\section{Recommendations}

1) The 1978 Land Use Act should be revised because government does not have control of land as stated on paper. There is a parallel land market in GPHC, i.e. the Land Use Act is not functioning as intended because individuals sell their family or inherited land at their discretion. The Land Use Act should be abrogated but government can create an enabling environment where land sale is regulated.

2) Government should provide an enabling environment for estate developers and to encourage investors through private sector involvement by public-private- partnership (PPP), public-public-partnership ( $\mathrm{Pb}-\mathrm{Pb}$ $\mathrm{P})$. Some of the measures mentioned in the research such as making land available for estate developers or regulating the price of land can be implemented.

\section{References}

[1]. Ajanlekoko J. S. (2001). Sustainable Housing Development in Nigeria- The Financial and Infrastructural Implication, International Conference on spatial Information for Sustainable Development, Nairobi, Kenya.16 September

[2]. Ede, P., Owei, O. B. \& Akarolo, C.(2011). Does the Greater Port Harcourt 2008 meet aspirations for liveable city? A Paper presented at the $47^{\text {th }}$ Congress of the International Society of City and Regional Planners. Liveable Cities: Urbanizing World, Meeting the Challenge. Wuhan.http://www.isocarp.net/ Data/case_studies/1859.pdf. Accessed (October $\left.4^{\text {th }}, 2014\right)$

[3]. Greater Port Harcourt City Development Authority (2009). http/www.GPHCDA/ (Accessed on: September 29, 2013).

[4]. Gobo, A.E; Amangabara, G.T and Agobie O,I (2014). Impacts of Urban Land use changes on flood events in Warri, Delta State Nigeria. Int. Journal of Engineering Research and Applications www.ijera.com ISSN : 2248-9622, Vol. 4, Issue 9( Version 3), September 2014, pp.48-60

[5]. Nubi, T.O. (2008) - Affordable Housing Delivery in Nigeria, Paper presented at The Southern African Housing Foundation International Conference and Exhibition, 12-15 October 2008 - Cape Town, South Africa.

[6]. Ogu, V.I. (1999). Housing enablement in a developing world city: The case study of Benin City, Nigeria. Habitat International, 23(2), 231-248. 